\title{
Diagnosis of Phytophthora in Soil Samples by Polymerase Chain Reaction
}

\author{
Touseef Hussain* \\ Plant Pathology Laboratory, Aligarh Muslim University, India \\ Received: 阱 January 22, 2018; Published: 阱January 30, 2018 \\ *Corresponding author: Touseef Hussain, Plant Pathology Laboratory, Aligarh Muslim University, India
}

\section{Introduction}

Phytophthora infestans is the most notorious causing Late blight of potato and tomato, globally. The word Phytophthora is derived from the Greek word: Phyto = plant, phthora = destroyer. Potato is a native of the North Andes (South America) and the late blight of potato was initially an endemic disease but in the mid1800s, late blight caused wide spread crop failures throughout the Northern Europe including Ireland where it was responsible for the Irish famine [1]. The genus Phytophthora represents a large group of plant pathogenic fungi responsible for crop losses in temperate and tropical climate [2]. Many species of Phytophthora are soil borne pathogens and spread through the movement of infested soil, or by water flow through infested soil [3]. A key element in the management of such diseases is the ability to detect the pathogen in soil and water. However, DNA extracted from soil contains substances such as humic acids, lignins, carbohydrates, resins, and so on which are very inhibitory to PCR amplification $[4,5]$. The amounts of inhibitory substances will vary widely with soil type, vegetation type, and composition of the soil micro flora. As the micro flora varies even over small distances (1 m scale) [6], the efficiency of PCR amplification is likely to vary widely even over small distances. It is therefore critical that an internal standard is used for PCR analysis of soil samples [7]. Recorded positive detection of P. infestans for up to twelve months from soil in which infested leaf tissue had been buried and for up to 24 months from soil containing leaf tissue infected with both mating types.

The difference is ascribed to the formation of sexual oospores in the doubly infected material. However [8] showed that infective propagules of P. cinnamomido not persist for long periods in soil. After incubation of infested soil for 12 weeks at $25^{\circ} \mathrm{C}$ the pathogen could not be detected by baiting, and although it could be detected by PCR the detection efficiency was significantly reduced. When the soil was incubated at $30^{\circ} \mathrm{C}$ for 12 weeks the pathogen could notbe detected by either baiting or PCR. For detection in soil, where there is no obvious lesiontissue to sample from, soil baiting has the advantage that it enables large amounts of soil $(0.5-1 \mathrm{~kg})$ to be tested whereas DNA extraction protocols are all based on extraction of small (1-10 g) samples. Consequently, with sampling for DNA extraction and analysis by PCR we may simply miss the pathogen. Baiting also has the advantage that it only detects viable pathogen. Recently [9] developed a new modified baiting method for detection P.infestans from potato agricultural fields. Despite the advantages, baiting is too slow and low throughput to be useful and can be subject to a high degree of false negatives also. The efficiency of detection of Phytophthora in soil by the baiting technique can be improved by sieving out the soil and rewetting it (double baiting demonstrating that, as with tissue sections, the pathogen, although present, will not always grow out of the sample $[10,11]$ found that double baiting increased the recovery of positive samples [12]. suggested that testing the bait water by PCR would have a number of advantages: (a) It overcomes the problem of sample size in relation to testing soil, (b) since we are testing water, problems with soil PCR inhibitory substances that co-extract with the DNA would be reduced, and (c) it also overcomes the problem that zoospores do not always infect the bait tissue leading to false negatives [13]. However, as discussed above in the section on soil baiting, viable pathogen may be present but only produce zoospores after washing and drying of the soil [14] Davison and Tay. These would not be detected by testing the bait water unless this additional step was routinely included in the baiting procedure. Dormant forms of the pathogen such as chlamydospores or oospores would also not be detected [15].

Reports that detection of the pathogen in soil is challenging and molecular detection may prove a valuable alternative to baiting methods. In recent years PCR has emerged as a powerful tool in plant disease diagnostics: it does not require the isolation 
of pure fungal cultures from infected tissue, and is often more sensitive, accurate, robust and rapid, less labour-intensive, and more economical than conventional diagnostics [16]. Described CTAB extraction and $\mathrm{NaOH}$ lysis methods for the extraction of DNA from oospores of P. infestans in pure culture. However, these methods cannot be applied to naturally infested soil samples. It may theoretically be possible to obtain oospores of P. infestans from naturally infested soils using a combination of sieving / sucrose gradients as demonstrated by $[17,18]$ for the quantification of oospores of Peronosporaviciae and P. capsici in soil, respectively [19]. Reported the abundant formation of oospores of P. infestans under field conditions has been recorded in Scandinavia and oospore- derived primary infections have been implicated in early disease epidemics since the 1990s [20]. In addition, this method is very labour intensive and visual identification of P.infestans propagules amongst oospores of other soilborne pathogens may be an issue [21] used a modified version of the method of [17] to recover oospores of $\mathrm{P}$. infestans from naturally infested field soils in the Toluca Valley of Central Mexico and classified soils as having low, moderate or high oospore counts if they contained 0-19, 2039 or $>39$ oospores/g soil, respectively. Percentage recovery could not be calculated in this case as soils were naturally infested. Lee, 2012 reported that in one of the methods of DNA extraction tested successfully released DNA from P. infestans oospores directly from soil or from oospores artificially added to soils or buffers. Oospores were observed microscopically to remain intact in all treatments and were undetectable using qPCR on any occasion [22] reported that oospores not only can be detected also quantified by Real time PCR (both A1 and A2 mating type) as well can be visualize their viability with MTT dye staining under microscope differentiation between dormant and germinating oospores. A new protocol was developed for DNA extraction from P.infestans oospores. The further development and use of DNA-based diagnostic techniques will also assist International efforts to control the introduction of exotic diseases into new geographic areas. Reliable and rapid techniques are needed by national and regional diagnostic laboratories to screen the planting material for important pathogens.

\section{References}

1. Elansky SN, Smirnov AN, Dyakov Y, Dolgova A, Filippov A, et al. (2001) Genotypic analysis of Russian isolates of Phytophtora infestans from the Moscow region, Siberia and Far East. J Phytopath 149: 605-611.

2. Judelson HS (1997) The genetics and biology of Phytophthora infestans: Modern approaches to a historical challenge. Fungal Genetics and Biology 22: 65-76.

3. Shearer BL, Tippett JT (1989) Jarrah Dieback: The Dynamics and Management of Phytophthora cinnamomiin the Jarrah (Eucalyptus marginata) Forest of South-Western Australia Perth. Dept of Conservation and Land Management 29: 201-215.

4. Tien C, Chao C, Chao W (1999) Methods for DNA extraction from various soils: a comparison. Journal of Applied Microbiology 86: 937-943.

5. Robe P, Nalin R, Capellano C, Vogel TA, Simonet P (2003) Extraction of DNA from soil. European Journal of Soil Biology 39: 183-190.
6. Scala DJ, Kerkhof LJ (2000) Horizontal heterogeneity of denitrifying bacterial communities in marine sediments by terminal restriction fragment length polymorphism analysis. Applied \&Environmental Microbiology 66: 1980-1986.

7. Hussain S, Lees AK, Duncan JM, Cooke DEL (2005) Development of a species-specific and sensitive detection assay for Phytophthora infestans and its application for monitoring of inoculum in tubers and soil. Plant Pathology 54: 373-382.

8. Anderson N (2006) DNA methods for detection of Phytophthora cinnamomifrom soil In: Biological Sciences PhD Thesis, Murdoch University Perth, Western Australia.

9. Hussain T, Singh BP, Anwar F, Tomar S (2015) A simple method for diagnostic of Phytophthora infestans from potato agricultural fields of potato. Turkish Journal of Agriculture Food science and Technology 3(12): 904-907.

10. Canaday C, Schmitthenner A (1982) Isolating Phytophthora megaspermaf sp glycineafrom soil with a baiting method that minimizes Pythium contamination. Soil BiolBiochem 14: 67-68.

11. Davison EM, Tay FCS (2005) How many soil samples are needed to show that Phytophthora cinnamomiis absent from sites in the south-west of Western Australia Australasian Plant Pathology 34: 293-297.

12. Nechwatal J, Schlenzig A, Jung T, Cooke DEL, Duncan JM, et al. (2001) A combination of baiting and PCR techniques for the detection of Phytophthora quercinaand P citricolain soil samples from oak stands. Forest Pathology 31: 85-97.

13. Wilson BA, Aberton J, Cahill DM (2000) Relationships between site factors and distribution of Phytophthora cinnamomiin the Eastern Otway Ranges. Australian Journal of Botany Victoria. 48: 247-260.

14. Jeffers SN, Aldwinkle HS (1987) Enhancing detection of Phytophthora cactorumin naturally infested soil. Phytopathology 77: 1475-1482.

15. Tooley PW, Bunyard BA, Carras MM, Hatziloukas E (1997) Development of PCR primers from internal transcribed spacer region 2 for detection of Phytophthora species infecting potatoes. Applied and Environmental Microbiology 63: 1467-1475.

16. Wangsomboondee T, Ristaino JB (2002) Optimisation of sample size and DNA extraction methods to improve PCR detection of different propagules of Phytophthora infestans. Plant Disease 86(3): 247-253.

17.Van der Gaag DJ, Frinking HD (1997) Extraction of oospores of Peronosporaviciae from soil. Plant Pathology 46(5): 675-679.

18. Pavón CF, Babadoost M, Lambert KN (2008) Quantification of Phytophthora capsici oospores in soil by sieving centrifugation and realtime polymerase chain reaction. Plant Dis 92: 143-149.

19. Stro“mberg A, Bostro"mU, Hallenberg N (2001) Oospore germination and formation by the late blight pathogen Phytophthora infestans in vitro and under field conditions. Journal of Phytopathology 149(11-12): 659-664.

20. Lehtinen A, Hannukkala A (2004) Oospores of Phytophthora infestans in soil provide an important new source of primary inoculums in Finland. Agricultural and Food Science 13: 399-410.

21. Ferna`ndez Pavi SP, Grunwald NJ, Diaz Valasis M, Cadena Hinojosa M, Fry WE (2004) Soilborne oospores of Phytophthora infestans in central mexico survive winter fallow and infect potato plants in field. Plant Disease 88(1): 29-33.

22. Hussain T, Singh BP, Firoz A (2014) A quantitative real time PCR based method for the detection of P. infestans causing late blight of potato, in infested soil. Saudi J Biol Sci 21(4): 380-386. 
CC (i) This work is licensed under Creative Commons Attribution 4.0 License

To Submit Your Article Click Here: Submit Article

DOI: $10.32474 / C I A C R .2018 .01 .000103$

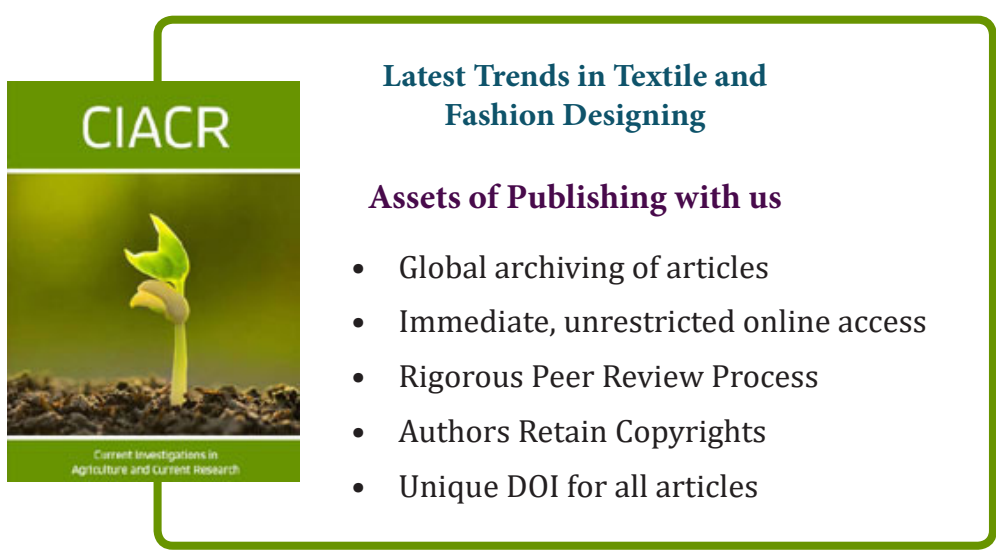

